\title{
Selection criteria for plant species grown on tin-mined soil in Bangka Island, Indonesia
}

\author{
E Nurtjahya Universitas Bangka Belitung, Indonesia
}

\begin{abstract}
Challenges in reclaiming tin-mined soil in Bangka Island, Indonesia are the declining quality of soil properties, metal and heavy metal contamination, and increasing acidity. A recent evaluation found leaf and root anatomical traits of species in ex tin mined soils were not correlated with survival rates, height growth or canopy areas. Thus, a renewed study focusing more on the functional traits to confirm morphological performance in the field is needed. Combining the study of leaf and root functional traits with the other physical trait studies may streamline the determination of species selection criteria for tin reclamation use. By studying samples of 92 plant species (24 herbs, 21 shrubs, 44 trees, and 3 lianas) grown in mined spoils and in forest fragments, focusing on 8 key functional traits, it is found that the leaf functional traits and root traits differed between plants grown in the ex-mined site and in the forest. Stomatal conductivities of several plant habits that grow on tin-mined soil were higher than those that grow on undisturbed land. Chlorophyll $a$ of herbs and lianas and chlorophyll $b$ in all habits, which were grown in ex-mined soils, were lower. Stomatal densities of herbs and lianas in-mined land were higher than plants grown in the forest. Leaf thickness, mesophyll and adaxial cuticle thickness of all habits grown in ex-mined spoils were higher than for plants grown in the forest. The enlarged palisade cells of those living in the dry ex-mined environment indicate their tolerance to water stress. In other study, the root conductivities in sedge and shrub species were higher in ex-mined soil compared to those grown in the undisturbed environments, while tree showed the opposite pattern. Some attributes are consistent with plants growing under greater water stress, therefore selection of species for regevetation should rely on those. The correlations of root and leaf traits are not consistent among herbs, shrubs, trees, and lianas and this might reflect different adaptive strategies. This inconsistency suggests that root conductivity, stomatal conductivity, and leaf nitrogen content in more species representing traits related to drought tolerance, regardless of growth habit, should be emphasized in the future studies.
\end{abstract}

Keywords: plant selection criteria, tin-mined soil, leaf and root, anatomical and physiological traits, growth form

\section{Introduction}

Land rehabilitation which leads to an improvement in land function, relies on adapted native plant species to be successful (van Andel et al. 2012). Reliance on natural succession in sandy tin tailings takes a long period of time before ground cover establishment (Ang 1994; Nurtjahya et al. 2009a). Reclamation of mined soils or, land rehabilitation, has been achieved in many areas. The use of adaptive local species is preferred but requires species selection. Local plant species must be selected based on their adaptations and the site characteristics of the reclaimed mined soil. Metal contamination, soil texture, and / or soil pH are additional challenges that need to be resolved.

In selecting plant species for revegetating tin mined soils, the selection was merely based on morphology. Exotic species such as Acacia mangium does not support biodiversity. The use of native species had not been studied extensively, and the selection was likely to be based on trial and error (Nurtjahya et al. 2008a). In some areas, the planting practices in mined land with vegetables, such as eggplant, maize, chili, long beans, and cucumber, with the compost and manure, showed success (Nurtjahya et al. 2009b). 
The identification of anatomical and physiological traits that can be used to identify species with potential to succeed in tin mined soils will greatly speed up the search for suitable local species. There has been a renewed interest in the use of ecophysiological characteristics as a mean for selecting suitable species, but only a few studies have applied this in revegetation of tin mines (Nurtjahya \& Franklin 2019).

The evaluation of local tree species in tin mined soil in the province of Bangka Belitung concluded that species with highest survival rates and cover development (Nurtjahya et al. 2008a) did not have superior adaptive measurements of their anatomical and physiological traits; the best adapted species were not those with the best performance in the site (Nurtjahya et al. 2011). The aim of this paper is to discuss the anatomical and physiological characteristics of plants that grow on tin-mined soils, in order to enrich species selection criteria.

\subsection{Tin mining}

Bangka Belitung islands are the second largest tin producing islands in the world. Tin has been exploited for many years (Figure 1). Mining activities take place offshore and onshore, including in protected marine ecosystems and forests. There are approximately 15,000 and 50,000 artisanal small-scale tin miners and about 30 private smelters (IDH 2013). Indonesia produced more than 100,000 tonnes of tin in 2013, which was nearly more than one third of world supply (IDH 2013). Mining has become an important economic driving force in the province ahead of pepper and rubber plantations (Zulkarnain et al. 2005). Tin production from small-scale tin mining contributed up to $80 \%$ of the country tin export (ITRI 2013).

Unfortunately, most of the unconventional tin mining activities are being carried out without regard to the safety of land reclamation and good mining practice. As a result, ecological disruption caused by tin mining continues for the sake of economic benefit. Studies show that efforts to restore tin-mined soils face significant challenges.

\subsection{Impacts on biota, microclimate, and soil quality}

Mining of alluvial cassiterite ( $\mathrm{SnO} 2$ ) is conducted after stripping the vegetation and removing the non-tin overburden. The extraction is done by applying large amounts of of high-pressure water jets to the sediment. The heavy tin ore is separated from light material by gravity in a series of shaking tables, jigs, including a traditional jig known as a sakan. Non-tin sediment flows towards the lower area in which the $\mathrm{pH}$ can go below 3 . Together with the other marginal lands, the total of disturbed lands may reach more than 5,000 ha including those that have been reclaimed and revegetated (Nurtjahya et al. 2009b).

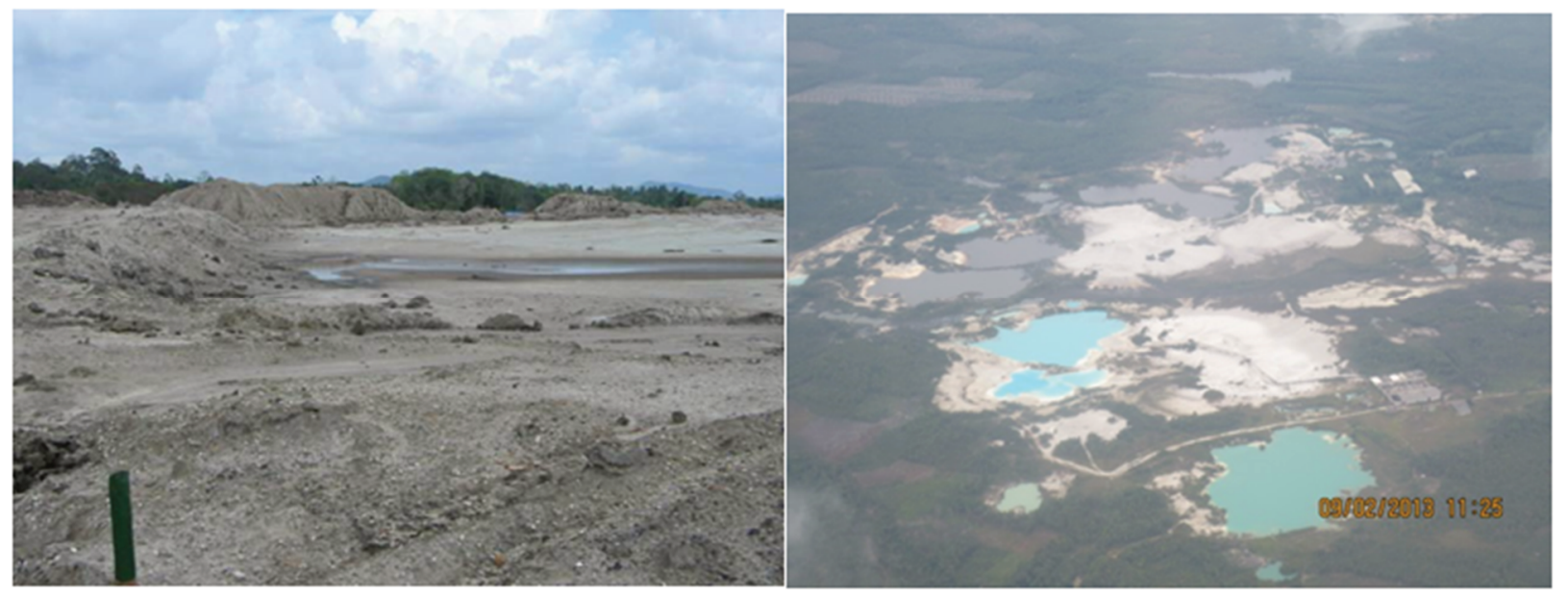

Figure 1 Inland mined sites (Nurtjahya et al. 2008; Nurtjahya 2013) 


\subsubsection{Soil quality}

Inland tin mining reduces soil fertility by reducing soil nutrients, metal and heavy metal contamination, and increasing acidity. Sand tailings may contain $95 \%$ sand with less than $2 \%$ organic carbon, and cation exchange capacity between 0.4-3.9 units (Nurtjahya 2008; Nurtjahya et al. 2009a). Phosphorus, potassium, and sodium concentrations in post tin mining soil were lower than those in undisturbed site (Nurtjahya et al. 2009a) (Table 1). There were differences of soil fertility in forest, abandoned farmed-land, and abandoned mined sites at $0,7,11$, and 38 years. The acidity $(\mathrm{pH})$ of newly mined site is $4.5-4.8$ and tends to be more acidic than the $\mathrm{pH}$ of 5 found in natural succession ex-mined land.

Table 1 Soil properties of riparian forest, abandoned farmed-land, 38-year-old tin-mined land, 11year-old tin-mined land, 7-year-old tin-mined land, and 0-year barren tin-mined land

\begin{tabular}{|c|c|c|c|c|c|c|c|c|c|c|c|c|c|c|c|c|c|c|}
\hline \multirow{4}{*}{ Study sites } & \multirow{3}{*}{ हू } & \multirow{3}{*}{ 胥 } & \multicolumn{2}{|c|}{ Texture } & \multirow{4}{*}{$\begin{array}{l}\mathrm{pH} \\
\\
\mathrm{H}_{2} \mathrm{O}\end{array}$} & \multicolumn{3}{|c|}{ Soil organic matter } & \multicolumn{2}{|c|}{$\mathrm{HCl} 25 \%$} & \multicolumn{7}{|c|}{ Cation-exchange } & \multirow{3}{*}{$\frac{\underline{z}}{\overline{\bar{y}}}$} \\
\hline & & & \multirow[b]{2}{*}{ \% } & \multirow{2}{*}{ 晃 } & & \multirow{2}{*}{ 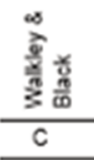 } & \multirow{2}{*}{ 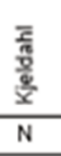 } & \multirow{3}{*}{$\mathrm{C} / \mathrm{N}$} & $0^{\circ}$ & O. & \multicolumn{7}{|c|}{ (NH4 - Acetate $1 \mathrm{~N}, \mathrm{pH} 7)$} & \\
\hline & & & & & & & & & & & $\overline{\mathrm{Ca}}$ & $\mathrm{Mg}$ & $K$ & $\mathrm{Na}$ & Total & CEC & 8 & \\
\hline & $\mathrm{cm}$ & \multicolumn{3}{|c|}{$\%$} & & \multicolumn{2}{|c|}{$\%$} & & \multicolumn{2}{|c|}{$\mathrm{mg} / 100 \mathrm{~g}$} & \multicolumn{6}{|c|}{$\mathrm{cmol}(+) / \mathrm{kg}$} & $\%$ & $\begin{array}{l}\mathrm{cmol} \\
(+) / \mathrm{kg}\end{array}$ \\
\hline Forest & $\begin{array}{r}0-20 \\
20-40\end{array}$ & $\begin{array}{l}78 \\
e 6\end{array}$ & $\begin{array}{l}13 \\
18\end{array}$ & $\begin{array}{l}10 \\
16\end{array}$ & $\begin{array}{l}4.7 \\
4.7\end{array}$ & $\begin{array}{l}1.6 \\
1.2\end{array}$ & $\begin{array}{l}0.2 \\
0.1\end{array}$ & $\begin{array}{l}10 \\
14\end{array}$ & $\begin{array}{l}22 \\
20\end{array}$ & $\begin{array}{l}5 \\
5\end{array}$ & $\begin{array}{l}0.2 \\
0.1\end{array}$ & $\begin{array}{l}0.1 \\
0.1\end{array}$ & $\begin{array}{l}0.1 \\
0.1\end{array}$ & $\begin{array}{l}0.1 \\
0.1\end{array}$ & $\begin{array}{l}0.4 \\
0.4\end{array}$ & $\begin{array}{l}5.8 \\
5.2\end{array}$ & $\begin{array}{l}7 \\
7\end{array}$ & $\begin{array}{l}2.0 \\
2.0\end{array}$ \\
\hline $\begin{array}{l}\text { Abandoned } \\
\text { farmed-land }\end{array}$ & $\begin{array}{r}0-20 \\
20-40\end{array}$ & $\begin{array}{l}47 \\
48\end{array}$ & $\begin{array}{l}22 \\
22\end{array}$ & $\begin{array}{l}31 \\
31\end{array}$ & $\begin{array}{l}4.5 \\
4.6\end{array}$ & $\begin{array}{l}3.2 \\
1.7\end{array}$ & $\begin{array}{l}0.3 \\
0.1\end{array}$ & $\begin{array}{l}12 \\
12\end{array}$ & $\begin{array}{l}35 \\
36\end{array}$ & 8 & $\begin{array}{l}0.3 \\
0.3\end{array}$ & $\begin{array}{l}0.2 \\
0.2\end{array}$ & $\begin{array}{l}0.1 \\
0.1\end{array}$ & $\begin{array}{l}0.0 \\
0.1\end{array}$ & $\begin{array}{l}0.7 \\
0.6\end{array}$ & $\begin{array}{r}14.7 \\
9.6\end{array}$ & $\begin{array}{l}4 \\
6\end{array}$ & $\begin{array}{l}4.8 \\
3.7\end{array}$ \\
\hline $\begin{array}{l}\text { Tin-mined } \\
\text { land } 38 \text { yrs }\end{array}$ & $\begin{array}{r}0-20 \\
20-40\end{array}$ & $\begin{array}{l}96 \\
95\end{array}$ & $\begin{array}{l}2 \\
2\end{array}$ & $\begin{array}{l}2 \\
3\end{array}$ & $\begin{array}{l}5.1 \\
5.0\end{array}$ & $\begin{array}{l}0.3 \\
0.2\end{array}$ & $\begin{array}{l}0.0 \\
0.0\end{array}$ & $\begin{array}{l}14 \\
10\end{array}$ & $\begin{array}{l}5 \\
4\end{array}$ & $\begin{array}{l}2 \\
2\end{array}$ & $\begin{array}{l}0.2 \\
0.1\end{array}$ & $\begin{array}{l}0.1 \\
0.1\end{array}$ & $\begin{array}{l}0.0 \\
0.0\end{array}$ & $\begin{array}{l}0.1 \\
0.1\end{array}$ & $\begin{array}{l}0.4 \\
0.3\end{array}$ & $\begin{array}{l}1.0 \\
0.8\end{array}$ & $\begin{array}{l}40 \\
31\end{array}$ & $\begin{array}{l}0.2 \\
0.2\end{array}$ \\
\hline $\begin{array}{l}\text { Tin-mined land } \\
\text { land } 11 \text { yrs }\end{array}$ & $\begin{array}{r}0-20 \\
20-40\end{array}$ & $\begin{array}{l}83 \\
80\end{array}$ & $\begin{array}{l}5 \\
3\end{array}$ & $\begin{array}{l}13 \\
18\end{array}$ & $\begin{array}{l}4.8 \\
4.8\end{array}$ & $\begin{array}{l}0.2 \\
0.3\end{array}$ & $\begin{array}{l}0.0 \\
0.0\end{array}$ & $\begin{array}{l}10 \\
10\end{array}$ & $\begin{array}{l}11 \\
11\end{array}$ & 4 & $\begin{array}{l}0.2 \\
0.2\end{array}$ & $\begin{array}{l}0.1 \\
0.1\end{array}$ & $\begin{array}{l}0.0 \\
0.0\end{array}$ & $\begin{array}{l}0.0 \\
0.0\end{array}$ & $\begin{array}{l}0.3 \\
0.4\end{array}$ & $\begin{array}{l}2.0 \\
2.3\end{array}$ & $\begin{array}{l}28 \\
30\end{array}$ & $\begin{array}{l}0.9 \\
0.9\end{array}$ \\
\hline $\begin{array}{l}\text { Tin-mined land } \\
\text { land } 7 \text { yrs }\end{array}$ & $\begin{array}{r}0-20 \\
20-40\end{array}$ & $\begin{array}{l}94 \\
93\end{array}$ & $\begin{array}{l}4 \\
6\end{array}$ & $\begin{array}{l}3 \\
2\end{array}$ & $\begin{array}{l}4.8 \\
4.8\end{array}$ & $\begin{array}{l}1.0 \\
1.2\end{array}$ & $\begin{array}{l}0.1 \\
0.1\end{array}$ & $\begin{array}{l}13 \\
14\end{array}$ & $\begin{array}{l}49 \\
71\end{array}$ & $\begin{array}{l}3 \\
3\end{array}$ & $\begin{array}{l}0.2 \\
0.2\end{array}$ & $\begin{array}{l}0.1 \\
0.1\end{array}$ & $\begin{array}{l}0.0 \\
0.0\end{array}$ & $\begin{array}{l}0.1 \\
0.1\end{array}$ & $\begin{array}{l}0.3 \\
0.4\end{array}$ & $\begin{array}{l}3.3 \\
3.0\end{array}$ & $\begin{array}{l}16 \\
19\end{array}$ & $\begin{array}{l}0.6 \\
0.7\end{array}$ \\
\hline $\begin{array}{l}\text { Barren tin- } \\
\text { mined land }\end{array}$ & $\begin{array}{r}0-20 \\
20-40\end{array}$ & $\begin{array}{l}94 \\
97\end{array}$ & $\begin{array}{l}2 \\
1\end{array}$ & $\begin{array}{l}4 \\
2\end{array}$ & $\begin{array}{l}4.8 \\
4.5\end{array}$ & $\begin{array}{l}0.2 \\
0.1\end{array}$ & $\begin{array}{l}0.0 \\
0.0\end{array}$ & $\begin{array}{l}15 \\
13\end{array}$ & $\begin{array}{l}2 \\
3\end{array}$ & $\begin{array}{l}3 \\
3\end{array}$ & $\begin{array}{l}0.1 \\
0.3\end{array}$ & $\begin{array}{l}0.2 \\
0.2\end{array}$ & $\begin{array}{l}0.0 \\
0.0\end{array}$ & $\begin{array}{l}0.0 \\
0.0\end{array}$ & $\begin{array}{l}0.3 \\
0.6\end{array}$ & $\begin{array}{l}0.4 \\
1.4\end{array}$ & $\begin{array}{l}73 \\
40\end{array}$ & $\begin{array}{l}0.3 \\
0.1\end{array}$ \\
\hline
\end{tabular}

Source: Nurtjabxa et al. 2009a

Land function analysis (LFA) of mined soils shows soil stability index, infiltration index, and nutrition cycle index are typically lower than those of undisturbed site (Wahyono et al. 2017) (Figure 2).

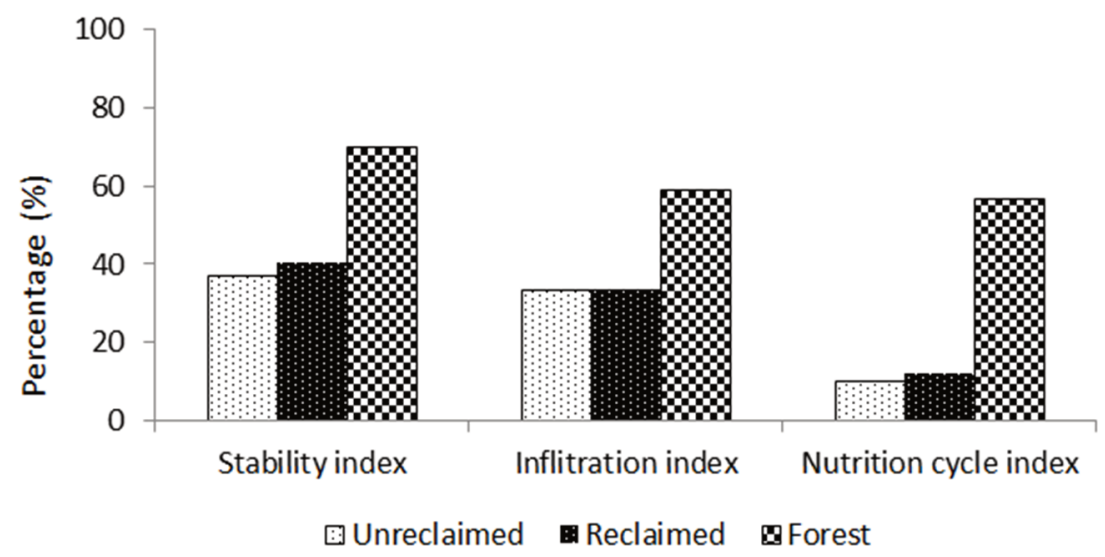

Figure 2 LFA indices, stability index, infiltration index, and nutrient cycle index of unreclaimed and reclaimed tin mined soil, and secondary forest (Wahyono et al. 2017)

\subsubsection{Microclimate}

Evaporation on tin mined land has been found to be higher than on undisturbed site at $4 \mathrm{~L} / \mathrm{m}^{2} / \mathrm{day}$, almost double the value on undisturbed land (Nurtjahya 2010, unpublished). Sand tailings need surface 
amendment before planting (Nurtjahya et al. 2009b), given that its soil temperature may reach $45^{\circ} \mathrm{C}$ during the day (Nurtjahya et al. 2008b).

\subsubsection{Biota}

Inland tin mining has been found to cause a decrease in the number of individual plants by up to $80 \%$ and the species up to $26 \%$. From studies in several locations in Bangka Island, mining activity changes vegetation structure and composition. For example, the similarity of vegetation structure of 38-year-old tinmined site was less than $2 \%$ of a nearby riparian forest (Table 2). Therefore, the appearance of poles and later trees in natural regeneration of the site may need much longer time (Nurtjahya et al. 2009a).

A study reported that the number of spores of arbuscular mycorrhizal fungi tends to increase with time since mining in sites abandoned naturally, but the total number of phosphate solubilizing bacteria shows the opposite (Nurtjahya et al. 2009a). The mesofauna Collembola population in revegetated tin mined soils vegetated with various native tree species increased after 6 months, 9 months, and 12 months after planting, with the average population of 374.9 individuals $/ \mathrm{m}^{2}$ and the highest record of $1,104.5$ individuals $/ \mathrm{m}^{2}$ (Nurtjahya et al. 2008b). The increasing Collembolan population was also reported at various age groups of tin mined lands planted with Acacia mangium, with 4,816 individuals $/ \mathrm{m}^{2}$ recorded at $13-$ year-old revegetation (Nurtjahya et al. 2007).

Table 2 Number of individual plants, species, and families in forest, abandoned farmed-land, 38-yearold tin-mined land, 11-year-old tin-mined land, 7-year-old tin-mined land, and 0-year-old barren tin-mined land

\begin{tabular}{|c|c|c|c|c|c|c|c|c|c|c|c|c|c|c|c|}
\hline \multirow[b]{2}{*}{ Study site } & \multicolumn{5}{|c|}{ Number of individuals / ha } & \multicolumn{5}{|c|}{ Number of species } & \multicolumn{5}{|c|}{ Number of families } \\
\hline & $\begin{array}{l}\text { seed } \\
\text { lings }\end{array}$ & $\begin{array}{l}\text { sap } \\
\text { lings }\end{array}$ & poles & trees & total & $\begin{array}{l}\text { seed } \\
\text { lings }\end{array}$ & $\begin{array}{l}\text { sap } \\
\text { lings }\end{array}$ & poles & trees & total & $\begin{array}{l}\text { seed } \\
\text { lings }\end{array}$ & $\begin{array}{l}\text { sap } \\
\text { lings }\end{array}$ & poles & trees & total \\
\hline Forest & 2,685 & 4,155 & 305 & 170 & 7,295 & 42 & 68 & 24 & 11 & 85 & 24 & 30 & 14 & 8 & 44 \\
\hline $\begin{array}{l}\text { Abandoned } \\
\text { farmed-land }\end{array}$ & 1.640 & 5.495 & 40 & 0 & 7.175 & 48 & 47 & 4 & 0 & 71 & 27 & 25 & 4 & 0 & 38 \\
\hline $\begin{array}{l}\text { Tin-mined } \\
\text { land } 38 \text { yrs }\end{array}$ & 2,125 & 55 & 0 & 0 & 2,180 & 15 & 1 & 0 & 0 & 16 & 12 & 1 & 0 & 0 & 13 \\
\hline $\begin{array}{l}\text { Tin-mined } \\
\text { land } 11 \text { yrs }\end{array}$ & 1,675 & 45 & 0 & 0 & 1,720 & 7 & 2 & 0 & 0 & 8 & 4 & 2 & 0 & 0 & 5 \\
\hline $\begin{array}{l}\text { Tin-mined } \\
\text { land } 7 \text { yrs }\end{array}$ & 890 & 0 & 0 & 0 & 890 & 6 & 0 & 0 & 0 & 6 & 4 & 0 & 0 & 0 & 4 \\
\hline $\begin{array}{l}\text { Barren tin-mined } \\
\text { land } 0 \text { yrs }\end{array}$ & 0 & 0 & 0 & 0 & 0 & 0 & 0 & 0 & 0 & 0 & 0 & 0 & 0 & 0 & 0 \\
\hline
\end{tabular}

Source: Nuctjabxa et al. 2009a

\subsection{Criteria determination}

Plant species selection depends on the purpose of revegetation: rehabilitation or economic (timber, food, herbal, or environmental service), or a combination of the two, as well as the biology of the species and its attributes. Species selection is governed by land condition - whether it is dry or wet, acid or normal soil, presence of metal contamination, or radioactivity - and also the neighbouring ecosystem. Also, the attribute of the species, i.e., early pioneer or late pioneer, is also taken into account when choosing suitable species for each stage of mined soil succession.

In selecting adapted species, plant water use characteristics are somewhat considered. Species with the lowest suction pressure tend to be selected for disturbed soil as different habits have different leaf suction pressures (Table 3). Tong et al. (2008) reported that the lowest leaf suction pressure is found in herbs, then shrubs, lianas, small trees, and big trees. For water stressed soils, the most adaptive plant species has the lowest daily transpirational water consumption. Decreasing transpiration also is also associated with increased of water use efficiency (Gonzalez-Rodriguez et al. 2010), which means better performance in unfavourable conditions. 
Table 3 Leaf suction pressure in relation to plant habit

\begin{tabular}{lc}
\hline Plant habit & Leaf suction pressure (atm) \\
\hline Herbs & 5.4 \\
Shrubs & 6.1 \\
Lianas & 12.4 \\
Small trees & 13.1 \\
Big trees & 15.1 \\
\hline
\end{tabular}

(Blum 1933 in Richards 1964)

Several criteria in selecting adaptive species have been reported. Evaluation on the basis of plant growth and its morphology is the most widely practiced. Good growth of the individual species in an unfavourable condition indicates that the species is adapted to the site. The study of anatomical and physiological traits has been used to validate good plant growth, but it has been concluded that anatomical and physiological characters were not well correlated with performance in the field (Nurtjahya et al. 2011). This also means that the chosen characteristics are either not relevant or not enough to make a difference. It should be remembered that the ex-mined soils are very diverse due to the local geology as well as differences in exploitation and the methods used. This dictates the physical, chemical, and biological properties of the tailings. In addition, the selection of species may often be based simply on seed availability and cost. Nurtjahya \& Franklin (2019) reported that species with a moderate growth rate, which can adapt in unfavourable reclaimed land, have more potential to be adopted.

\section{Methodology}

\subsection{Site description}

Bangka Island with the area of 1.17 million hectares (PPTA 1996) lies off the eastern coast of south Sumatra and has the population of 1,192,028 (Badan Pusat Statistik 2021). The climate of the area is hot and humid and belongs to Af type according to Köppen-Geiger classification (PT Timah Tbk. 1997). The average temperature is $26.3^{\circ} \mathrm{C}$ with average humidity and rainfall of $61 \%$, and $241 \mathrm{~mm}$ per month respectively. December and January have the highest precipitation and August and September having the lowest (Nurhuda et al. 2016). The landscape is flat with an average of $50 \mathrm{~m}$ above the sea level, but with several hills with the highest elevation of 700 metres.

\subsection{Data collection}

The study has been developed through review of recent research articles written by colleague and student of Universitas Bangka Belitung and the author (Nurtjahya \& Santi 2018; 2019; Nurtjahya \& Savira 2020). Samples were collected from mined soils and the neighbouring forest in Bangka, Central Bangka, South Bangka, and West Bangka regencies.

This paper measured eight functional traits, including leaf morphology (leaf thickness, stomatal density), and anatomical traits (mesophyll thickness, adaxial cuticle thickness, root conductivity of total area of root xylem at transversal cross section), and physiological traits (stomatal conductance, foliar nitrogen concentration, and foliar pigment concentrations) of 92 plant species ( 24 herbs including sedge and grasses, 21 shrubs, 44 trees and 3 lianas). The plant species were in ex tin mined spoils and fragment forests and comprised 75 families and 39 genera (Nurtjahya \& Santi 2018; 2019; Nurtjahya \& Savira 2020).

Stomatal conductance, using an AP4 porometer apparatus (Delta-T, Cambridge, UK), was measured in situ in sunny days with three repetitions, and on three individuals of each species, between 07:00 and 11:00. Leaves were harvested for nitrogen and pigment analysis. Samples for pigment analysis were stored at $-4^{\circ} \mathrm{C}$ and then approximately $0.2 \mathrm{~g}$ of leaf tissue was extracted in $80 \%(\mathrm{v} / \mathrm{v})$ acetone. Pigments in extracts were determined colorimetrically (Spectrophotometer, USA) at wavelengths of 480,663, and $645 \mathrm{~nm}$. Pigment concentrations are calculated based on the fresh weight using equations by Sesták et al. (1971) for 
chlorophylls a and b, and equation of Davies (1965) for carotenoids, and Kjeldhal method for nitrogen. The test was conducted at the university laboratory (Nurtjahya \& Santi 2018). For paradermal measurement, leaf samples were fixed with $70 \%$ alcohol, stained with safranin with wholemount method of Sass (1951). For transversal measurement, leaf and root cut samples were fixed in FAA solution with paraffin method of Johansen (1940). The measurements were conducted in the university laboratory (Nurtjahya \& Santi 2019).

\section{$3 \quad$ Results and Discussions}

\subsection{Leaf stomatal conductance, stomatal density and leaf thickness}

Stomatal conductance varies with growth habit, with shrubs having the highest values (Figure 3 ). In herbs and shrubs from mined land, stomatal conductance is higher and significantly different than those in the forest. For all growth habits, stomatal conductance is higher in plants from mined land than those in the forest (Nurtjahya \& Santi 2018). No significant effect of soil type was observed. These readings are different from the other studies that observed stomatal conductance of plants which are subjected to water-stress is expected to be lower than those on undisturbed soils (Setiawan et al. 2013; Liu et al. 2014). For the herbs, comprising 5 grasses, 5 sedges, and 14 herbs, the stomatal conductance readings might also be influenced by whether they are C3 and C4 species. C4 grass species consistently show lower stomatal conductance than C3 grasses, which is associated with their smaller stomata (Taylor et al. 2012). The relatively high readings might be correlated with the soil moisture either in the ex-mined spoils, or in the forest bed (Wu et al. 2020). In their study, Yu et al. (2015) stated that stomatal conductance of a particular species is sensitive in the range of $20-60 \%$ soil moisture, insensitive when soil moisture content was below $20 \%$.

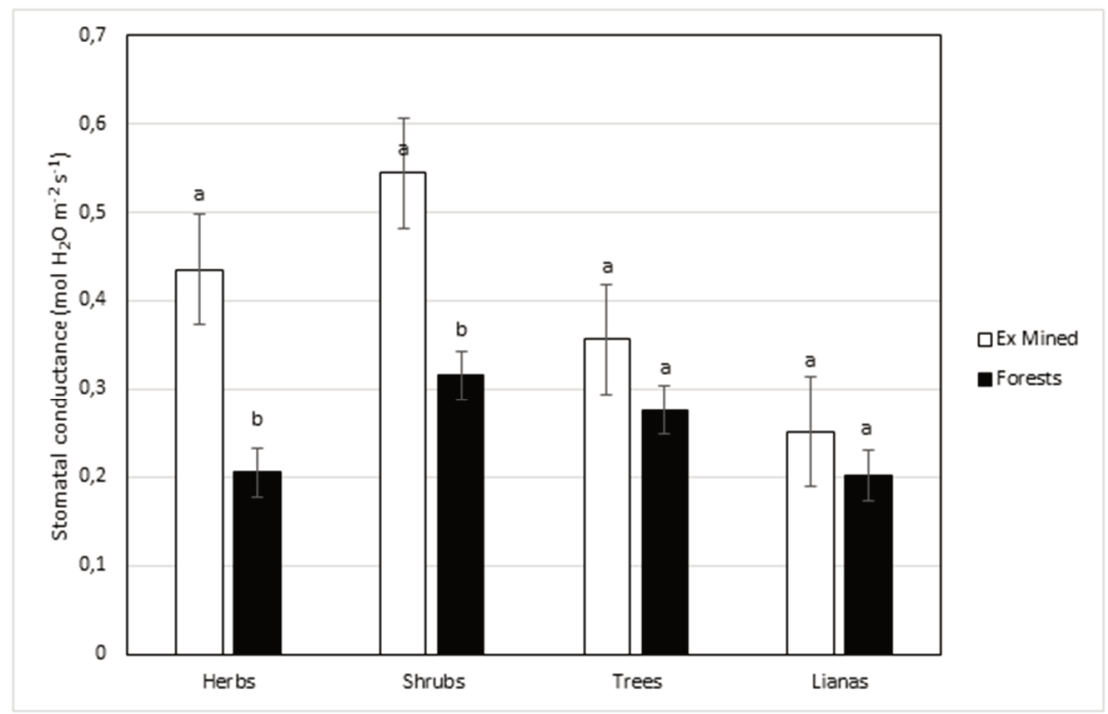

Note: Bars indicate standard error. Different letters indicate differences between location for a given habitus at $\alpha 0.05$.

Figure 3 Stomatal conductance of plants grown in tin-mined soil and in the forest (Nurtjahya \& Santi 2018)

Stomatal density is another variable between growth habits, with shrubs also having the highest value (Figure 4). Stomatal density of plants from mined land is higher and significantly different than forest plants, except in shrubs (Nurtjahya \& Santi 2019). A significant effect of soil type was found during the study.

Greater stomatal density in plants on mined sites compared to those on undisturbed soils was also reported in Commersonia bartramia and Trema orientalis (Juairiah et al. 2005), in Syzygium grande, Calophyllum inophyllum, and Vitex pinnata (Nurtjahya et al. 2011), and Lotus creticus (Banon et al. 2004). These findings are also reported by Willmer (1983). The density increase is to compensate for the reduction 
of leaf area due to water stress which is to reduce transpiration (Sutcliffe 1979). However, plants which show their adaptation to water stress may have stomatal density that is similar or lower to those on undisturbed environment (Dobrenz et al. 1969).

In similar study with temperate and subtropical plants, Liu et al. (2019) found similar results and suggested that leaf traits were not consistent among herbs, shrubs, and trees, which indicates different adaptive strategies.

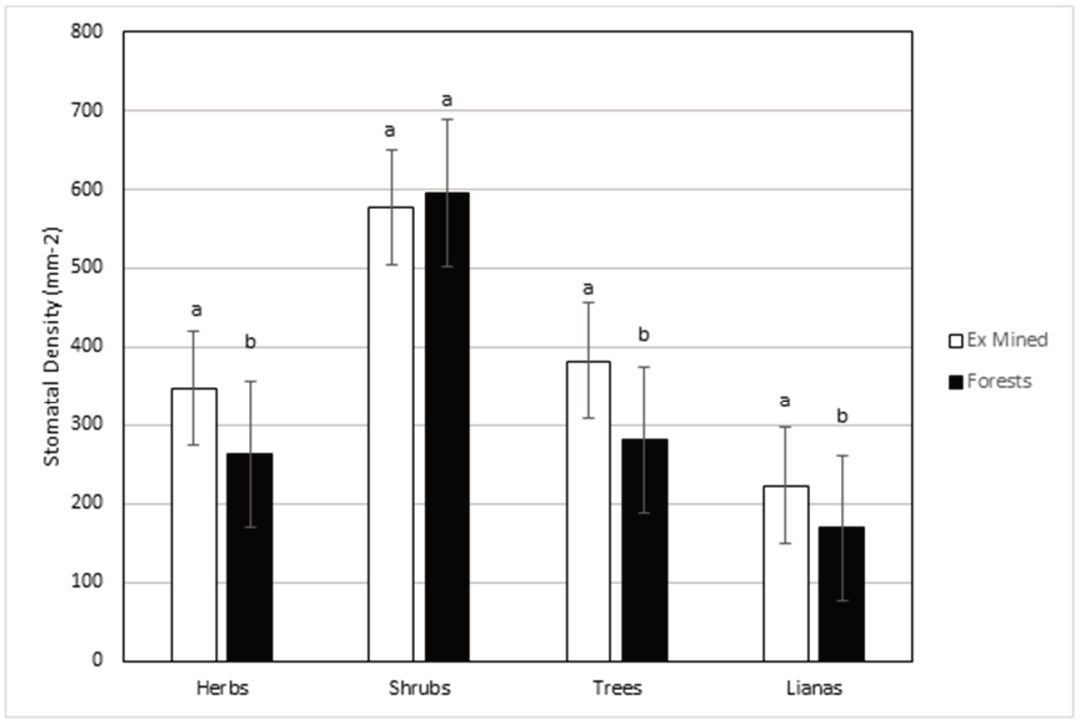

Note: Bars indicate standard error. Different letters indicate differences between location for a given habitus at $\alpha 0.05$.

Figure 4 Stomatal density of plants grown in tin-mined soil and in the forest (Nurtjahya \& Santi 2019)

Leaf thickness is a variable within the growth habits (Figure 5). Leaf thickness of plants, particularly lianas, in mined land is thicker than in the forest (Nurtjahya \& Santi 2019). A significant effect of soil type was found. Mesophyll and adaxial cuticle thickness of all plants from mined land are higher than those in the forest. A significant mesophyll difference was also found in lianas, and a significant adaxial cuticle thickness difference was shown in trees.

Enlarged palisade cells of plants living on dry environment might show their tolerance to water stress (Poejiastuti 1994), and more pigment can take place in these palisade cells. In other studies, mesophyll layer can have longer and more layers in higher light intensity (Taiz \& Zeiger 2002; Dickison 2000). The leaf changes can be related to the photosynthesis efficiency. Thicker epidermal cells might control transpiration and prevent leaves from excessive sunlight (Nurtjahya \& Juairiah 2012; Nurtjahya et al. 2011). 


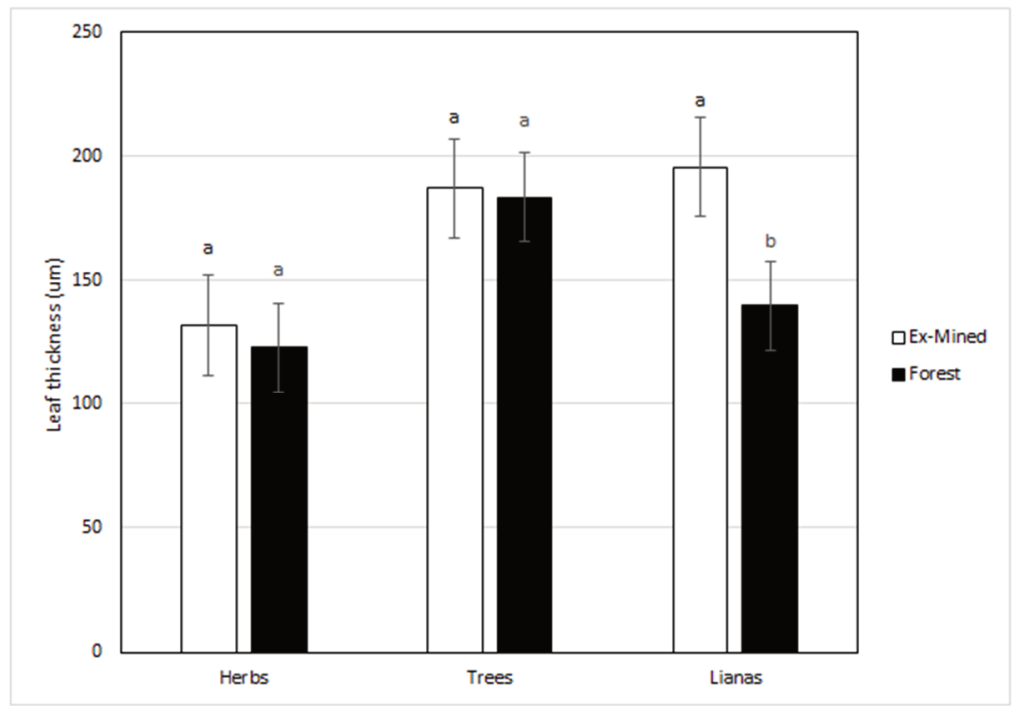

Note: Bars indicate standard error. Different letters indicate differences between location for a given habitus at $\alpha 0.05$.

Figure 5 Leaf thickness of plants grown in tin-mined soil and in the forest (Nurtjahya \& Santi 2019)

Chlorophyll concentration of herbs and lianas plants growing in mine land were significantly lower than those grown in the forest. Similarly, chlorophyll $b$ concentrations of all habits grown in mined land were lower compared to those grown in the forest, and the differences in shrubs and lianas plants are significant (Nurtjahya \& Santi 2018). Carotenoid concentrations are higher in ex-mined soils than in forest in herbs, shrubs, and trees. Carotenoid concentration in lianas in ex-mined is significantly lower than in the forest. For chlorophylls $a$ and b, significant effects of soil type were found. Leaf nitrogen is another variable within the habits (Figure 6). Leaf nitrogen in plants from mined land is higher than those in the forest, for herbs and trees. No significant effect of soil type was found.

Chlorophyll a is decreased for the leaf of herbs and lianas grown in ex-mined soils, while the decrease of chlorophyll $b$ in all habits grown in ex-mined soils was observed. These might be correlated to the decrease of leaf nitrogen in shrubs and lianas. There is a positive correlation between foliar nitrogen concentration and chlorophyll and available soil nitrogen (Prsa et al. 2007).

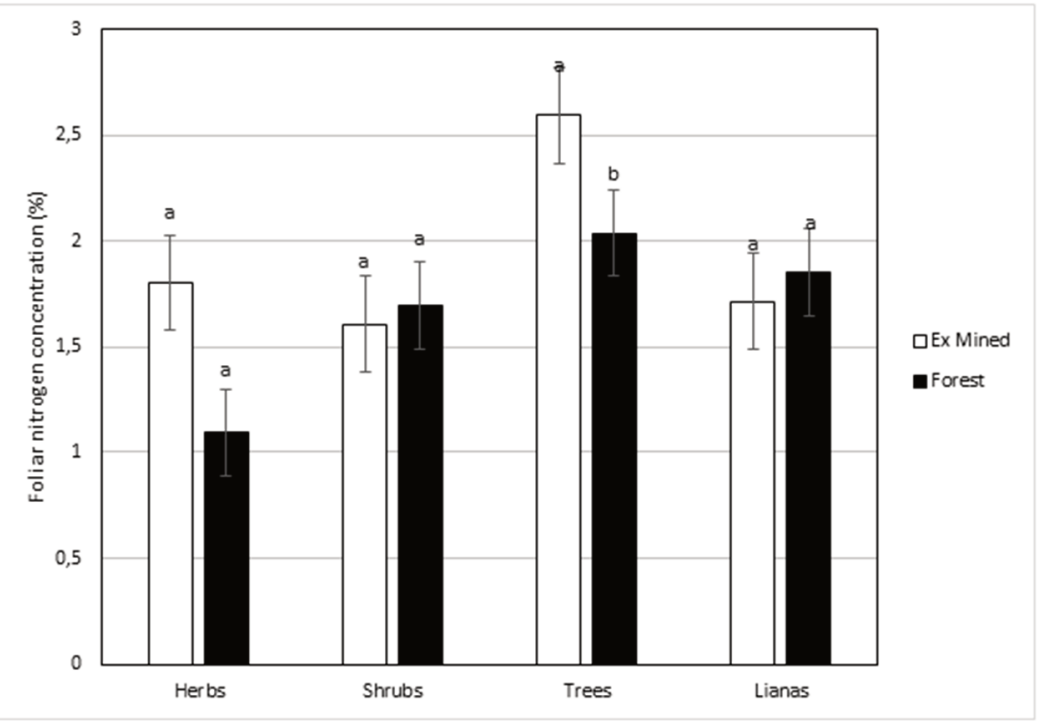

Note: Bars indicate standard error. Different letters indicate differences between location for a given habitus at $\alpha 0.05$.

Figure 6 Leaf nitrogen of plants grown in tin-mined soil and in the forest (Nurtjahya \& Santi 2018) 


\subsection{Root conductivity}

Root conductivity of total area of root xylem at transversal cross section of Scleria levis (sedge), Melastoma malabatrichum (shrub) was higher in mined soil compared to those grown in the undisturbed environments, while Acacia mangium (tree) showed an opposite pattern (Nurtjahya \& Savira 2020) (Figure 7). These findings correlate with the higher root diameter, higher number of total bundles, and xylem diameter of plants grown in mined soils, compared to those in undisturbed environment, however $A$. mangium showed the opposite pattern. In the field, $S$. levis population outnumbered the population of $M$. malabatrichum and $A$. mangium. It suggested that $S$. levis has a dehydration tolerance mechanism, which enables it to adapt to water stress environment with less changes anatomically (Sopandie 2013).

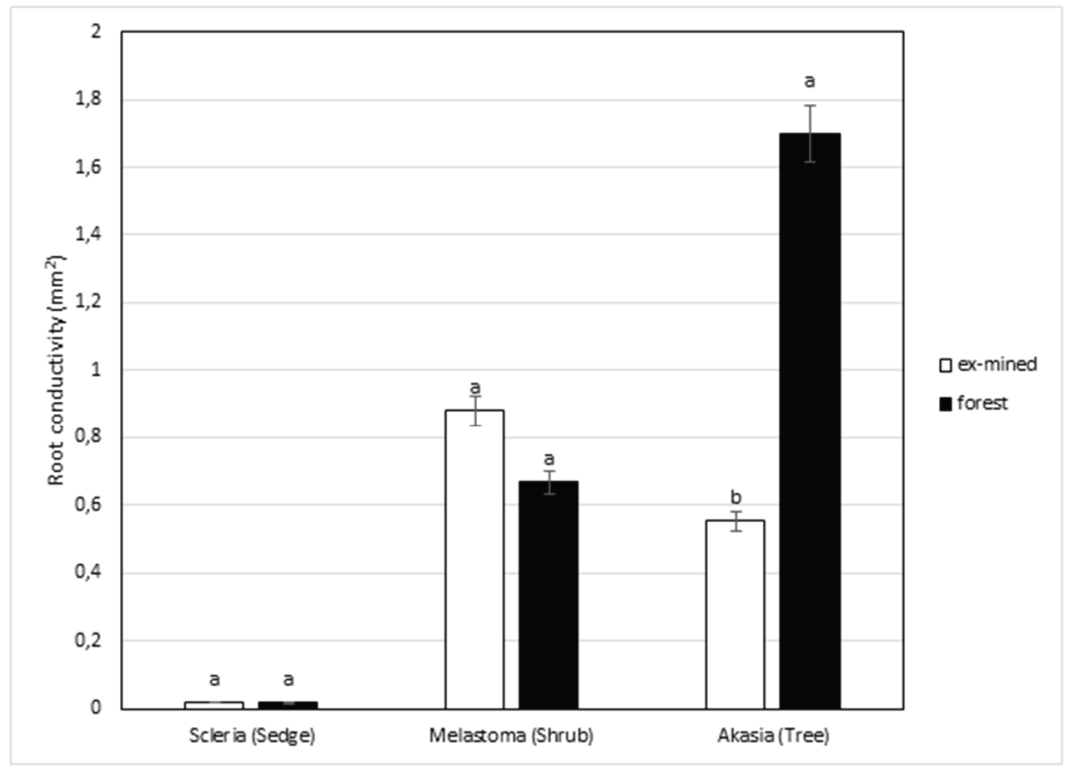

Note: Bars indicate standard error. Different letters indicate differences between location for a given habitus at $\alpha 0.05$.

Figure 7 Root conductivity of plants grown in tin-mined soil and in the forest (Nurtjahya \& Savira 2020)

\section{$4 \quad$ Conclusions}

In this study of plant attributes when growing in land mined for tin or natural forest, there were differences in leaf functional traits and root traits. Stomatal conductance, stomatal density, leaf thickness, and mesophyll and adaxial cuticle thickness were all higher for plants grown in mined land than those grown in the forest.

Enlarged palisade cells of plants on dry environments might show their tolerant to water stress. The decrease of chlorophyll $a$ in the leaf of herbs and lianas grown in ex-mined soils, and the decrease of chlorophyll $b$ in all habits grown in ex-mined soils, might be correlated to the increase of leaf nitrogen in shrubs and lianas. The root conductivities in sedge and shrub species were higher in ex-mined soil compared to those grown in the undisturbed environments, while tree showed the opposite pattern.

Some attributes are consistent with plants growing under greater water stress, therefore selection of species for regevetation should rely on those. The correlations of root and leaf traits are not consistent among herbs, shrubs, trees, and lianas which might reflect their different adaptive strategies. This inconsistency indicates that anatomical traits, regardless of the growth habit, should be emphasized in the future studies. 


\section{Acknowledgement}

The author gratefully acknowledges the research reports of Penelitian Dasar "Dinamika transpirasi berbagai habitus tanaman di lahan bekas tambang timah Bangka" (No. 120.A/UN50.3.1/PP/2018; and No. 185.B/UN50.3.1/PP/2019), which were funded by Directorate General of Higher Education, Ministry of Research, Technology and Higher Education, Republic of Indonesia, and the author also acknowledge to colleagues Dr. Ratna Santi, and Ms. Savira, S.Si. in data collection. Special thanks to the reviewers for their valuable comments on the manuscript.

\section{References}

Ang, LH 1994, 'Problems and Prospects of Afforestation on Sand Tin Tailings in Peninsular Malaysia', Journal of Tropical Forest Science, vol. 7 no.1, pp. 87-105.

Badan Pusat Statistik, 2021, Penduduk menurut Kabupaten Kota (Jiwa/Orang) 2018-2020, viewed 23 February 2021 , https://babel.bps.go.id/indicator/12/1028/1/penduduk-menurut-kabupaten-kota.html

Banon, S, Fernandez, JA, Franco, JA, Torrecillas, A, Alarcon, JJ \& Sanchez-Blanco, MJ 2004, 'Effects of Water Stress and Night Temperature Preconditioning on Water Relations and Morphological and Anatomical changes of Lotus creticus Plants', Scientia Horticulturae vol. 101, pp. 333-342.

Davies, BH 1965, Analysis of carotenoid pigments, in TW Goodwin (ed), Chemistry and Biochemistry of Plant Pigments, Academic Press, New York.

Dickison, WO 2000, Integrative Plant Anatomy, Academic Press, Tokyo.

Dobrenz, AK, Wright, LN, Humprey, AB, Massergale, MA \& Kneebone, WR 1969, 'Stomatal density and its relationship to water use efficiency of blue panigrass (Panicum antidotale Retz.)', Crop Science vol. 9, pp. 354-357.

Gonzalez-Rodriguez, AM, Baruch, Z, Palomo, D, Cruz-Trujillo, G, Jimenez, MS \& Morales, D 2010, 'Ecophysiology of the invader Pennisetum setaceum and three native grasses in the Canary Islands', Acta Oecologica, vol. 36, pp. 248-254.

IDH 2013, IDH Tin working group communiqué - To share recent study findings and consult Indonesian stakeholders about their sustainability views and priorities for action, IDH, UK.

International Tin Research Institute, ITRI 2013, Indonesia's position in the global tin industry, ITRI Indonesia Tin Forum, Pangkalpinang.

Johansen, DA 1940, Plant microtechnique, McGraw-Hill, New York.

Juairiah, L, Nurtjahya, E, Prawitasari, T \& Dorly 2005, 'Konduktivitas Xilem Akar dan Batang Tumbuhan Pionir di Lahan Pasca Penambangan Timah di Desa Sempan, Bangka, in Prosiding Pertemuan Ilmiah Nasional \& Expo IPTEK MIPA 2005, Universitas Indonesia, Jakarta.

Liu, C, Li, Y, Xu, L \& He N 2019, 'Variation in leaf morphological, stomatal, and anatomical traits and their relationships in temperate and subtropical forests', Scientific Reports, vol. 9, no. 5803, pp. 1-8, doi:10.1038/s41598-019-42335-2.

Liu, G, Li, X, Jin, S, Liu, X, Zhu, L, Nie, Y \& Zhang, X 2014, 'Improves Drought and Salt Tolerance by Enhancing Root Development and Reducing Transpiration Rate in Transgenic Cotton', PLOS ONE, vol. 9, no. 1, 10p.

Nurhuda, M, Bisri, A, Setiawan, N, Prihatiningsih, ED, Yulianto, T, Fadholi, A, ...\& Kusumo, I 2016, Karakteristik Curah Hujan Pulau Bangka Berdasarkan Data Chirps (Climate Hazard Group Infrared Precipitation with Station Data). Laporan Internal Stasiun Meteorologi Klas 1Pangkalpinang, Pangkalpinang.

Nurtjahya, E 2008, Revegetasi Lahan Pasca Tambang Timah dengan Beragam Jenis Pohon Lokal di Pulau Bangka, PhD thesis, Institut Pertanian Bogor, Bogor.

Nurtjahya E \& Juairiah L 2012, 'Anatomical and Physiological Characteristics of reclamation plant on the post-mining land in Riding Panjang, Bangka', Jurnal Teknologi Indonesia, vol. 35, no. 3, pp. 52-58.

Nurtjahya, E \& Franklin, J, 2019, 'Some Physiological Characteristics to Estimate Species Potential as a Mine Reclamation Ground Cover', The International Journal of Mining, Reclamation and Environment, vol. 33, no. 2, pp. 75-86.

Nurtjahya, E, Robika \& Dorly 2011, 'Can anatomical and physiological characters predict plant adaptation on tin-mined land in Bangka Island?, in AB Fourie, M Tibbett \& A Beersing (eds), Proceedings of the $6^{\text {th }}$ International Conference on Mine Closure, Australian Centre for Geomechanics, Perth, pp. 75-83.

Nurtjahya, E \& Santi, R 2018, Dinamika transpirasi berbagai habitus tanaman di lahan bekas tambang timah Bangka. Laporan Penelitian Dasar Tahun 1. Kementrian Riset, Teknologi dan Pendidikan Tinggi, No. 120.A/UN50.3.1/PP/2018, Universitas Bangka Belitung, Bangka.

Nurtjahya, E \& Santi, R 2019. Dinamika transpirasi berbagai habitus tanaman di lahan bekas tambang timah Bangka. Laporan Penelitian Dasar Tahun 2. Kementrian Riset, Teknologi dan Pendidikan Tinggi, No. 185.B/UN50.3.1/PP/2019, Universitas Bangka Belitung, Bangka.

Nurtjahya, E \& Savira 2020, Karakter anatomi rumput di lahan bekas tambang timah di Bangka. Laporan Internal, Universitas Bangka Belitung, Bangka.

Nurtjahya E, Setiadi, D, Guhardja, E, Muhadiono \& Setiadi, Y 2007, 'Populasi Collembola di Lahan Revegetasi Tailing Timah di Pulau Bangka', Biodiversitas, vol. 8, no.4, pp. 309-313. 
Nurtjahya, E, Setiadi, D, Guhardja, E, Muhadiono \& Setiadi, Y 2008a, 'Establishment of four local tree species for potential revegetating of tin-mined land in Bangka Island, Indonesia', in A Fourie, M Tibbett, I Weiersbye \& P Dye (eds), Proceedings of The Third International Seminar on Mine Closure, Australian Centre for Geomechanics, Perth, Australia, pp. 751-758.

Nurtjahya, E, Setiadi, D, Guhardja, E, Muhadiono \& Setiadi, Y 2008b, 'Revegetation of tin-mined land using various local tree species in Bangka Island, Indonesia', in RI Barnhisel (ed), Proceedings America Society of Mining and Reclamation, ASMR, Lexington, pp. 739-755.

Nurtjahya, E, Setiadi, D, Guhardja, E, Muhadiono \& Setiadi, Y 2009a, 'Succession on tin-mined land in Bangka Island', Blumea, vol. 54, no. 1-3, pp. 131-138.

Nurtjahya, E, Nur, MM \& Mulyono, E 2009b, 'Rice field cultivation on tin-mined land in Bangka Island, Indonesia', in AB Fourie \& M Tibbett (eds), Proceedings of Mine Closure, Australian Centre for Geomechanics, Perth, pp. 549-560.

Poejiastuti, E 1994, Studi Komparatif Anatomi Daun Beberapa Genotif Kedelai (Glycine max (L)) yang Peka dan Toleran terhadap Cekaman Kekeringan, undergraduate thesis, Institut Pertanian Bogor, FMIPA, Bogor.

Prsa, I, Stampar, F, Vodnik, D \& Veberic, R 2007, 'Influence of Nitrogen on Leaf Chlorophyll Content and Photosynthesis of 'Golden Delicious' Apple', Acta Agriculturae Scandinavica, Section B - Plant Soil Science, vol 57, no. 3, pp. 283-289.

PT Timah Tbk. 1997, ANDAL, RKL, dan RPL. Kegiatan Penambangan Timah dan Pasir Laut di Perairan P. Bangka Kabupaten Bangka, Propinsi Sumatera Selatan, PT Timah Tbk., Pangkalpinang

Pusat Penelitian Tanah dan Agroklimat, PPTA 1996, Laporan Akhir Penelitian Studi Upaya Rehabilitasi Lingkungan Penambangan Timah, Pusat Penelitian Tanah dan Agroklimat, Departemen Pertanian, Bogor.

Richards, PW 1964, The tropical rain forest, Cambridge University Press, Cambridge.

Sass, JE 1951, Botanical microtechnique, 2nd edn, lowa State College Press, Ames.

Sesták, ZD, Čatskŷ, J \& Jarvis PG 1971, Determination of chlorophylls a and b, in Z Sesták, J Čatskŷ \& PG Jarvis (eds), Plant photosynthetic production: Manual of Methods, Junk NV, The Hague.

Setiawan, Tohari \& Shiddieq D 2013, 'Pengaruh cekaman kurang air terhadap beberapa karakter fisiologi tanaman nilam (Pogostemon cablin Benth)', Jurnal Littri, vol. 19, no. 3, pp. 108-116.

Sopandie, D 2013, Fisiologi Adaptasi Tanaman terhadap Cekaman Abiotik pada Agroekosistem Tropika, Institut Pertanian Bogor Press, Bogor.

Sutcliffe, JF 1979, Plants and Water 2nd edn, Edward Arnold, London.

Taiz, L \& Zeiger, E 2002, Plant Physiology, The Benjamin / Cummings Pub. Co. Inc., California.

Taylor, SH, Franks, PJ, Hulme, SP, Spriggs, E, Christin, PA, Edwards, EJ, ...\& Osborne, CP 2012, 'Photosynthetic pathway and ecological adaptation explain stomatal trait diversity amongst grasses', New Phytologist, vol. 193, pp. 387-396.

Tong C, Gong J-Z., Marrs, R, Zhang, I \& Wang, W-Q 2008, 'Pattern of transpiration of four shrub species and water consumption from shrub stands in an eco-reclamation catchment in northwest China', Arid Land Research and Management, vol. 22, pp. 242-254.

van Andel J, Grootjans, AP \& Aronson J 2012, 'Unifying Concepts' in J Aronson, J van Andel (eds) Restoration Ecology: The New Frontier, 2nd edn, Blackwell Publishing Ltd., Oxford.

Wahyono, Y, Nurtjahya, E \&Putra, HF 2017, Analisis Keberhasilan Revegetasi Lahan Pasca Tambang Timah di Bangka Tengah, Seminar Hasil Penelitian, Jurusan Biologi, Universitas Bangka Belitung, Bangka.

Willmer, CM 1983, Stomata, Longman Inc., New York.

Wu, J, Serbin, SP, Ely, KS, Wolfe, BT, Dickman, LT, Grossiord, C, \& Roger, A 2020, 'The response of stomatal conductance to seasonal drought in tropical forests', Global Change Biology, vol. 26, no. 2, pp. 823-839.

Yu, M-H, Ding, G-D, Gao, G-L, Zhao, Y-Y, Yan, L \& Sai, K 2015, 'Using Plant Temperature to Evaluate the Response of Stomatal Conductance to Soil Moisture Deficit', Forests, vol. 6, pp. 3748-3762.

Zulkarnain, I, Erman, E, Pudjiastuti, TN \& Mulyaningsih, Y 2005, Konflik di Kawasan Pertambangan Timah Bangka Belitung: Persoalan dan Alternatif Solusi, LIPI Press, Jakarta. 